\title{
THE PRESIDENT'S REPORT ON HIS VISIT TO CANADA AND THE UNITED STATES, SUMMER, I952
}

At the suggestion of the National Parks Association of the United States and on the invitation of the National Parks Service, I was privileged, as representing your Society, to visit two of America's most beautiful national parks, Olympic and Mount Rainier. They are both situated in Washington State, known as the Evergreen State, in the north-west of the U.S.A. They consist of rain forests, colossal cedars, firs, and snowcapped mountains.

I was most impressed by the mass of technical knowledge being collected on all subjects by the rangers, and the manner in which such knowledge was imparted to the many visitors to the parks. The trouble taken to make visitors feel at home and happy was most impressive; the present expenditure and future estimates for roads, rest camps, and hostels are on a vast scale.

In Canada I visited both Banff and Jaspar National Parks and was made an honorary member of "The Trail Riders". I had the pleasure of meeting that great naturalist Mr. Dan McCowan and of making two broadcasts on your behalf over the Canadian radio system.

In Toronto I was entertained at an evening reception by Mr. R. Fennell, Q.C., the President, and by Dr. Urquhart, the Technical Director of the Royal Ontario Museum. I also accepted, as a gift from the well-known firm of Carling Breweries Limited, two instructional films on the life of the moose and the elk to add to the Society's library.

In New York our Vice-President, Dr. Van Name, introduced me to Mr. H. E. Anthony, Director of the Natural History Museum, and other officials, and I spent a most interesting afternoon with them, seeing amongst other things the collection made by our good friend Mr. Arthur Vernay, who is doing so much for the preservation of the flamingo in the Bahamas.

The following day Lady Willingdon and myself were entertained to luncheon by the Zoological Society in their magnificent gardens at The Bronx. This was followed by a tour of the gardens. Amongst those present was Dr. Van Straelen, President of the National Parks Institute of the Belgian Congo, who was most enthusiastic about recent developments in Uganda. Mr. Fairfield Osborn, President of the New York Zoological Society 
and author of that great book "Our Plundered Planet" has kindly sent a message to our Society. It is given below.

I finish by saying that I believe these personal contacts, when they can be arranged, are invaluable and help to smooth the way for the innumerable international problems which are bound to crop up in endeavouring to further the aims of our Society and the preservation and conservation of nature as a whole.

WiLLingdon.

A Message to the Members of the Fauna Preservation Society from Mr. Fairfield Osborn

\section{WILDERNESS}

There are essences in human life which defy analysis. Who can measure the influence upon the human spirit of an inspiring passage of music or of a radiant line of poetry or prose? The inner being of man is forever something apart from utilitarian or material influences. The story of Christ going into the wilderness has been accepted through the ages not merely as a symbol but as an essential episode in the personality of an individual. "I will lift up mine eyes unto the hills from whence cometh my help" is a prayer flowing naturally from the human heart that senses the oneness of the individual and the natural world.

Our era is one of pressures from without. There is nothing startling in this-it is the way of man, indeed of all life. Faiths have always required defence as have all precious things. Among the latter is "wilderness". We in America still possess such regions, a diminishing few-sanctuaries where even the wildest creatures are quiet and at home. Let's not let them disappear-they give strength to those who go to them, and always will.

Fairfield Osborn.

\section{THE SOCIETY'S BUSINESS}

Notice of a General Meeting

A General Meeting of the Society will take place at the Offices of the Zoological Society of London on 'Tuesday, 2nd December, 1952, at 4.15 p.m. 